\title{
As políticas linguísticas nos PALOP e o desenvolvimento endógeno
}

\author{
Rajabo Alfredo Mugabo Abdula \\ Universidade Estadual Paulista Júlio de Mesquita Filho \\ Alexandre António Timbane \\ Universidade Federal de Goiás \\ Duarte Olossato Quebi \\ Pesquisador Independente - Guiné-Bissau
}

\section{Introdução}

Em todo mundo, as línguas desempenham um papel importante na comunicação. É através dela que se estabelecem laços de pertença étnica, política, econômica ou cultural. África, apesar de ser um continente sofrido por causa da colonização, aproveita muito pouco os recursos linguísticos disponíveis para criar um desenvolvimento que emerge dos próprios africanos. Nesse contexto, muitas línguas africanas estão em vias de extinção por causa de políticas governamentais que não protegem, ou melhor, que dão um status sociocultural e político a essas línguas. Algumas delas são inteligíveis por serem do mesmo grupo ou família linguística, como é o caso das línguas zulu (da África do Sul), siswati (da Suazilândia), o ronga, xichangana, o xitswa (de Moçambique).

A presente pesquisa versa sobre as políticas e o planejamento linguístico empreendido pelo sistema colonial e pós-colonial nos países africanos, em particular nos Países Africanos de Língua Oficial Portuguesa (PALOP). Pretende-se discutir como a política linguística colonial comparticipou na exploração e retardamento do desenvolvimento dos PALOP. Pretende-se propor ideias que visam superar esse impasse, introduzindo políticas que possam contribuir com a valorização das línguas africanas na direção do desenvolvimento e de contatos entre os próprios países africanos. Como ponto de partida, refletimos sobre as seguintes questões: i) África como berço da humanidade; ii) como um dos primeiros continentes que introduziu a escrita; iii) como continente com recursos naturais invejáveis; e iv) subdesenvolvimento e perda da sua riqueza linguística. 
A primeira hipótese é a de que a colonização criou uma ideia de inferioridade das nossas línguas, de tal forma que não as usamos para fins legais; a segunda é a de que os governantes que alcançaram as independências esqueceram a sua identidade linguística, favorecendo e dando maior prestígio às línguas dos colonizadores; a terceira é que há falta de pesquisas que incentivem o desenvolvimento africano baseado em políticas que privilegiam as línguas locais. Sendo assim, propomos uma discussão acerca de como se aproveitar a riqueza linguística com vistas ao desenvolvimento econômico, político e cultural dos africanos. Sabe-se que o português é língua oficial nos PALOP e as línguas africanas e o crioulo são relegadas às relações de comunicação informais, quer dizer, relações de comunicação local. Nota-se ainda que muitos políticos não têm capacidade de se expressar em português e, por isso, sentem-se limitados para oferecerem suas contribuições nos plenários da Assembleia da República. A fim de suscitar essa discussão, é importante distinguir-se política linguística de planejamento linguístico, pelo fato de cada um exigir um tratamento específico nos estudos linguísticos. Inicialmente, a política linguística, por um lado, está voltada

para uma prática de caráter estatal-legislativo, debruçando-se, por exemplo, sobre a oficialização de línguas, a escolha de alfabeto para a representação gráfica de uma língua, a hierarquização formal das línguas (línguas de trabalho, oficiais, nacionais, por exemplo, entre outros (Severo, 2013, p. 451).

Por outro lado, o planejamento linguístico se interessa pela prática, pela implementação (Calvet, 2007) da política que é, na verdade, a sua aplicação prática no seio de uma determinada sociedade. Por exemplo, o ensino nas escolas, o uso na elaboração de documentos da função pública, o uso de uma língua na justiça - tudo isso está no âmbito do planejamento. Isso significa que o planejamento cumpre ordens da política linguística. Para que haja uma política linguística, portanto, é necessário que haja atributos sociolinguísticos básicos, tal como se observa no quadro 1 :

Quadro 1: Atributos sociolinguísticos

\begin{tabular}{|c|l|}
\hline Estatuto & \multicolumn{1}{|c|}{ ATRIBUTOS SOCIOLINGUÍSTICOS REQUERIDOS } \\
\hline Oficial & $\begin{array}{l}\text { 1. Padronização } \\
\text { 2. Utilizada corretamente por certo número de cidadãos escolarizados }\end{array}$ \\
\hline & $\begin{array}{l}\text { 1. Símbolo de identidade nacional para uma parte importante da população } \\
\text { 2. Amplamente utilizada na comunicação cotidiana }\end{array}$ \\
Nacionalista & $\begin{array}{l}\text { 3. Ampla e frequentemente falada no país } \\
\text { 4. Sem alternativa maior no país para a mesma função } \\
\text { 5. Aceitável como símbolo de autenticidade } \\
\text { 6. Ligada a um passado glorioso }\end{array}$ \\
\hline
\end{tabular}




\begin{tabular}{|c|l|}
\hline De grupo & $\begin{array}{l}\text { 1. Utilizada por todos na conversação cotidiana } \\
\text { 2. Considerada pelos falantes como unificando-os e distinguindo-os dos } \\
\text { demais }\end{array}$ \\
\hline Veicular & 1. Considerada como adquirível por, pelo menos, uma maioria do país \\
\hline Internacional & 1. Presente na lista das línguas internacionais potenciais \\
\hline Escolar & 1. Padronização igual ou maior do que a língua dos alunos \\
\hline Religiosa & 1. Clássica \\
\hline
\end{tabular}

Fonte: Fasold apud (Calvet, 2007, p.46)

Essa visão apresentada no quadro 01 (Escolha de língua oficial) tem uma perspectiva eurocentrista, pois privilegia bastante a escrita. E os povos africanos são, em sua maioria, de tradição oral, o que significa que não possuem chances de ver as suas línguas com o estatuto de oficiais. Com relação à língua nacional, está claro que as línguas africanas receberiam apenas esse estatuto, tal como a Constituição da República de Moçambique aponta no seu art.9. Ao nosso ver, o português é língua nacional, uma vez que tem a função de unir linguisticamente as etnias que falam as diversas línguas bantu moçambicanas. Por seu turno, o crioulo é uma língua nacional (nos países onde ocorre), pois corresponde às necessidades comunicativas dos cabo-verdianos, guineenses e são tomenses. É importante sublinhar que a Constituição da República da Guiné-Bissau e a Constituição da República Democrática de São Tomé e Príncipe não decidiram nada sobre as suas línguas. Isso significa que não houve nenhuma política linguística tomada em nível da lei-mãe: a constituição. Observando ainda o quadro 01, percebe-se que São Tomé e Príncipe e Guiné-Bissau não incluíram suas línguas em pelo menos um dos estatutos apresentados no quadro, o que é grave ao nosso ver.

Olhando para a estrutura do capítulo, temos, na primeira parte, uma discussão sobre a situação linguística dos PALOP e sobre como as línguas coloniais foram aplicadas no sistema colonial, estratégia que cimentou a presença do português nos PALOP e, com isso, observamos as consequências dessa política linguística na vida dos africanos. Num segundo momento, discutimos as particularidades do português africano, em particular a 'nativização' do português de África, e o surgimento dos crioulos de base portuguesa. Numa terceira e última seção, debatemos como os africanos devem aproveitar a riqueza linguística vasta para o desenvolvimento endógeno em todas as esferas econômica, educacional e sociocultural. Comecemos pela situação linguística dos PALOP. 


\section{Situação linguística dos Países Africanos de Língua Oficial Portuguesa (PALOP)}

Em todas as sociedades, a língua é instrumento de comunicação que estabelece relações entre os membros da sociedade. Qualquer que seja a língua, ela necessariamente identifica um grupo social. As línguas bantu, por exemplo, identificam um macro-grupo etno-linguístico que contempla mais de 600 línguas localizadas geograficamente da África Central até a Austral. As línguas bantu, segundo Greenberg (2010, p.329-330), dividem-se em dois subgrupos: (a) Níger-congo que compreende grande parte da África ao sul do Saara, incluindo quase toda a África Ocidental, partes do Sudão central e oriental, sendo que seu sub-ramo bantu ocupa a maior parte da África central, oriental e meridional e; (b) Niger-kordofaniano: confina-se a uma zona limitada da região do kordofan no Sudão.

Esta classificação se justifica pelas características linguísticas que são comuns. Usando o método comparativo, o linguista Guthrie (1948) percebeu que as semelhanças consistiam em: (a) o uso extensivo de prefixos; (b) cada substantivo pertence a uma classe; (c) cada idioma pode ter dez ou mais classes; (d) a classe é indicada por um prefixo no substantivo, como também em adjetivos e verbos que concordam com aquele, e (e) o plural é indicado por uma mudança de prefixo.

Foram encontradas 16 zonas principais que se estendem desde a África oriental até o sul de África. Para além das famílias Níger Níger-congo e kordofaniano, é preciso destacar que, ao se considerar os PALOP, mais precisamente a República de Angola, há também línguas da família Khoisan, que são línguas faladas por pequenos grupos de populações localizadas geograficamente no deserto do Kalahari, na Namíbia e Angola, mas também em Botsuana, Tanzânia e Quênia. Contudo, omaior grupo populacional dos khoisan localiza-se na África do Sul. A sua característica mais notória é o uso de cliques na sua fala. As línguas khoisan se subdividem em três ramos: hatsa, sandawe e khoisan sul-africano (Greenberg, 2010, p.334).

Os PALOP têm uma diversidade linguística bem vasta. Para além das línguas bantu, khoisan e dos crioulos, apresentam o português como a língua de prestígio, que é resultado das políticas e planejamento linguístico impostos pelo sistema colonial, isto porque a colonização portuguesa criou, assim, um africano de tipo novo. Destribalizado, não sabendo, por vezes, falar a língua local, impelido para as estruturas organizacionais europeias e, enfim, urbanizado, o assimilado desempenha, plenamente, o seu papel de pilar da colonização (Jorge, 2006). Tal como veremos na seção 2, a colonização inventou um africano linguisticamente diferente, de tal forma que este foi perdendo a sua própria identidade. Vejamos, em seguida, o Quadro 2 que indica as línguas faladas em diferentes PALOP, sem contar com português que é a princípio língua oficial: 
Quadro 2: Línguas faladas nos PALOP sem incluir português

\begin{tabular}{|c|c|c|c|c|c|c|}
\hline & $\begin{array}{c}\text { Moçambique } \\
\text { (2007) }\end{array}$ & $\begin{array}{l}\text { Angola } \\
(2012)\end{array}$ & $\begin{array}{l}\text { Guiné-Bissau } \\
\text { (2009) }\end{array}$ & $\begin{array}{c}\text { Guiné } \\
\text { Equatorial } \\
\text { (2016) }\end{array}$ & $\begin{array}{l}\text { Cabo Verde } \\
\text { (2010) }\end{array}$ & $\begin{array}{c}\text { São Tomé e } \\
\text { Príncipe } \\
(2012)\end{array}$ \\
\hline $\begin{array}{c}\text { L } \\
\text { I } \\
\text { N } \\
\text { G } \\
\text { U } \\
\text { A } \\
\text { S }\end{array}$ & $\begin{array}{l}\text { kimwani, ciwu- } \\
\text { te, shimakon- } \\
\text { de, ciyaawo, } \\
\text { e m a k huwa, } \\
\text { e c h u w a - } \\
\text { bu, cinyanja, } \\
\text { c in y u g gwe, } \\
\text { cisena, cindau } \\
\text { cibalke, ciwu- } \\
\text { te, cimanyika, } \\
\text { gitonga, citswa } \\
\text { cicopi, xichan- } \\
\text { gana, xirhonga }\end{array}$ & $\begin{array}{l}\text { kimbumdu, } \\
\text { kikongo, } \\
\text { tchokwé, } \\
\text { nganguela, } \\
\text { umbundu, } \\
\text { ndong a, } \\
\text { oshiwam- } \\
\text { bo, nya- } \\
\text { neka, } \\
\text { héhéro, } \\
\text { khoisan }\end{array}$ & $\begin{array}{l}\text { crioulo, ba- } \\
\text { lanta, man- } \\
\text { dinga, papel, } \\
\text { fula, manca- } \\
\text { nha, felúpe, } \\
\text { bijagó, man- } \\
\text { jaco }\end{array}$ & $\begin{array}{l}\text { espanhol } \\
\text { francês } \\
\text { batanga } \\
\text { benga } \\
\text { ngouma } \\
\text { séké } \\
\text { yassa } \\
\text { fá d'ambô } \\
\text { fang }\end{array}$ & $\begin{array}{l}\text { kabu- } \\
\text { verdiano }\end{array}$ & $\begin{array}{l}\text { santomen- } \\
\text { se ou for- } \\
\text { ro (base } \\
\text { da língua } \\
\text { kwa): } \\
\text { principe- } \\
\text { ense ou } \\
\text { lunguyè, } \\
\text { angolar, } \\
\text { anobonen- } \\
\text { se ou fá } \\
\text { d'ambu }\end{array}$ \\
\hline $\begin{array}{l}\text { Total } \\
\text { Pop. }\end{array}$ & $\begin{array}{l}22.416 .881 \\
\text { hab. }\end{array}$ & $\begin{array}{l}17.429 .637 \\
\text { hab. }\end{array}$ & $\begin{array}{l}1.515 .224 \\
\text { hab. }\end{array}$ & $\begin{array}{l}759.451 \\
\text { hab. }\end{array}$ & $\begin{array}{l}494.040 \\
\text { hab. }\end{array}$ & $\begin{array}{l}163.784 \\
\text { hab. }\end{array}$ \\
\hline
\end{tabular}

Fontes: Ngunga e Faquir (2011); Pereira (2006); Kukanda (2000), CPLP (2013), Abdula (2003); Couto (s.d.).

A escrita das línguas de Moçambique apresentadas no Quadro 2 foi padronizada em 2008, no $3^{\circ}$ Seminário de Padronização da Ortografia de Línguas Moçambicanas. É importante acrescentar que para além dessas línguas, em Moçambique se fala kiswahli, ekoti, élomwé, xiswati, isizulu (Sitoe, 2014). Nessa lista de línguas moçambicanas, inclui-se ainda a Língua Moçambicana de Sinais que é, muitas vezes, esquecida, como se população surda não existisse no país.

A diversidade linguística fez com que o português falado nos PALOP fosse diferente do falado em Portugal, país de origem, ou seja, nota-se um distanciamento com relação à norma-padrão europeia. Segundo Lucchesi e Baxter (2009, p.101) e Naro e Scherre (2007, p.135), esse processo é chamado de Transmissão Linguística Irregular ${ }^{1}$. Essas condições históricas e culturais fizeram com que surgisse a pidginização e crioulização ocorrida na Guiné-Bissau, São Tomé e príncipe e Cabo Verde. Para o caso de Moçambique e Angola não houve pidginização nem crioulização, porque as condições sócio-históricas não favoreciam, uma vez que as línguas bantu faladas nesses dois países mantiveram-se fortes em função do número de falantes e pela dispersão das populações ao longo dos vastos territórios. Caso os portugueses quisessem se comunicar com os moçambicanos

1. "Tal processo de nativização da língua dominante ocorre de maneira irregular no sentido de que os dados linguísticos primários de que as crianças que nascem nessas situações dispõem para desenvolver a sua língua materna provêm praticamente de versões de segunda língua desenvolvidas entre os falantes adultos das outras línguas, que apresentam lacunas e reanálises em relação aos seus mecanismos gramaticais” (Lucchesi, Baxter, 2009, p.101). 
e angolanos, havia muitos intermediários bilíngues (como os missionários, os cipaios e os mercadores) que faziam as traduções. Segundo Pereira (2006, p.68)

também não foi fácil ao português impor-se em tão extensos territórios, dado o número diminuto dos seus falantes em comparação com o número de falantes de línguas africanas, de implementação secular. Por outro lado, a estabilidade e o isolamento dos diferentes grupos rurais africanos e a sua pouca mobilidade fortaleciam o uso das línguas maternas entre populações autóctones.

É importante mostrar que a implementação do português como língua oficial foi regida pela Constituição ${ }^{2}$ de cada um dos países. Assim sendo, ao observar a Constituição de cada um dos PALOP, nota-se o interesse pela promoção da língua oficial, a língua portuguesa, e pouco se faz menção ao destino das diversas LB, do khoisan e dos crioulos falados pelos cidadãos residentes no espaço dos PALOP. Esse aspecto se junta às elevadas taxas de analfabetismo desses países.

Acerca disso, o uso de uma língua desconhecida aos alunos no espaço escolar tem criado muitos problemas, dentre os quais se podem apontar as reprovações em massa como o principal. Adiciona-se a essa situação: i) o fraco investimento por parte dos Governos na área da educação; ii) a distância entre a casa dos alunos e a escola, principalmente nas áreas rurais; iii) turmas superlotadas e fraca formação de professores; e iv) a pobreza absoluta. Alguns pesquisadores não dão valor a esta última questão, mas sabemos que uma criança alimentada consegue ficar mais atenta na aula do que aquela que chega à escola sem ter comido alguma coisa no café da manhã ou no almoço. Se a escola providenciasse um almoço (merenda, como é designado no Brasil), iria manter mais alunos, pois a fome é, sem dúvidas, um encalço para a sua presença na escola. Nesse contexto, vejamos a evolução das taxas de abandono escolar de 2009 para 2014 nos PALOP.

Quadro 3: Taxas de abandono escolar nos PALOP

\begin{tabular}{|c|c|c|}
\hline PAIS & Percentagem (ano) & Percentagem (ano) \\
\hline Cabo Verde & $17,2 \%(2010)$ & $10,7 \%(2014)$ \\
\hline São Tome e Príncipe & $8,2 \%(2009)$ & $33,9 \%(2014)$ \\
\hline Guiné Equatorial & $*$ & $27,9 \%(2014)$ \\
\hline Angola & $34,4 \%(2009)$ & $68,1 \%(2014)$ \\
\hline Guiné-Bissau & $45,8 \%(2010)$ & $*$ \\
\hline Moçambique & $49,9 \%(2009)$ & $69,4 \%(2014)$ \\
\hline \multicolumn{2}{|c|}{ Fonte: CPLP (2013, p.100) e IDH (2014) } \\
\hline
\end{tabular}

2. República de Angola (2010); República de Moçambique (2004), República de Cabo Verde (1990); República Democrática de São Tomé e Príncipe (2003) e República da Guiné-Bissau (1996). 
Observando o Quadro 3, nota-se que a República Democrática de São Tomé e Príncipe e Cabo Verde são os países que apresentam taxas mais baixas de abandono (27,9\% e 10,7\% respectivamente), em função do número de habitantes (cf. Quadro 2) que é muito reduzido. Os restantes países apresentam taxas elevadas. Os casos mais gritantes são Moçambique e Angola, cujas taxas de abandono superam a 50\%, isto é, metade da população estudantil não consegue finalizar seus estudos. Cabo Verde apresentou uma redução considerável de abandono escolar de 2009 para 2014. O país passou de $17,2 \%$ para $10,7 \%$, o que significa que as políticas locais incentivam as crianças a permanecer na escola. Os restantes PALOP observam com passividade as taxas de abandono estudantil que tendem a crescer ao longo dos anos.

Ao se considerar uma hipótese para a reversão desse quadro, cremos que o primeiro passo seria a valorização das línguas africanas e, para que isso ocorra, deve-se oficializá-las nos países e nos locais onde elas são faladas. Nesse sentido, Tanzânia, Uganda e Quênia oficializaram a língua swahili em paralelo com a língua do colonizador e, até o momento, nunca acompanhamos notícias de guerras provocadas por esta tomada de decisão. Sublinhamos que o swahili é uma língua oficial da União Africana, falada por cerca de 50 milhões de africanos espalhados pelo continente, incluindo Moçambique, República Democrática do Congo, Burundi, Uganda, Ruanda, Somália, Zâmbia, Etiópia, Tanzânia, Quênia, entre outros.

A África do Sul oficializou 10 línguas africanas e jamais ouvimos existência de conflitos devido ao uso dessas línguas. Isso mostra que a não oficialização não tem nada a ver com a divisão étnica dos povos, mas com vontade política. Dessa forma, os resultados dessa teimosia política resultam em taxas altas de abandono escolar e de analfabetismo. Nelson Mandela (1918-2013), grande líder africano dizia: "a educação é a arma mais poderosa que você pode usar para mudar o mundo". Algumas atitudes políticas mostram claramente que "remam em sentido contrário' à perspectiva de Mandela.

O Quadro 4 mostra como as taxas de analfabetismo são altas num momento em que se deseja apostar na educação de qualidade em todo mundo. Os números falam por si e ilustram como os povos africanos ainda não alcançaram suas independências. A colonização indireta por parte de Governantes revela como a guerra ainda deve ser enfrentada para que haja igualdades econômicas e linguísticas: 
Quadro 4: Taxa de analfabetismo nos PALOP

\begin{tabular}{|c|c|c|c|}
\hline País & $\begin{array}{c}\text { Taxa de } \\
\text { analfabetismo }\end{array}$ & País & $\begin{array}{c}\text { Taxa de } \\
\text { analfabetismo }\end{array}$ \\
\hline Angola & $34,4 \%(2009)$ & Moçambique & $49,9 \%(2009)$ \\
\hline Cabo Verde & $17,2 \%(2010)$ & São Tomé e Príncipe & $8,2 \%(2009)$ \\
\hline Guiné-Bissau & $45,8 \%(2010)$ & Guiné-Equatorial & $*$ \\
\hline
\end{tabular}

Fonte: CPLP (2016, p.100)

* sem informação

Terminamos esta seção sublinhando que a situação sociolinguística nos PALOP é muito complexa, pois há várias línguas que disputam o mesmo espaço e os mesmos falantes. A língua portuguesa tende a evoluir contrariando as diversas línguas bantu, khoisan e crioulos. Essas línguas não são protegidas pelas políticas linguísticas e, por isso, em alguns casos - como as do grupo khoisan, por exemplo -, tendem a desaparecer. Os PALOP não precisariam correr esse risco se adotassem políticas que visam fomentar o uso e a expansão dessas línguas. Na próxima seção, veremos como o sistema colonial implementou as políticas de dominação usando como o escudo o domínio ou não do português.

\section{Implementação das línguas no período colonial}

Nesta seção, discutiremos como o sistema colonial português utilizou a LP para dominar e colonizar os povos africanos. O primeiro conceito a discutir é o de dialeto. Com a chegada do sistema colonial, as línguas africanas passaram a ser desvalorizadas. A educação colonial privilegiava o português, ensinando o povo africano a ler e a escrever. Segundo Timbane (2013, p.264) "um dialeto não é uma língua, pois esse termo traz uma sensação preconceituosa, uma sensação de inferioridade." Todas as línguas africanas eram consideradas dialetos ${ }^{3}$ pela ideologia colonial, termo pejorativo porque todas as línguas africanas têm as mesmas competências que outra língua qualquer, quer dizer, têm uma gramática, um léxico, uma morfologia, uma sintaxe próprias. Segundo Bagno (2011, p.380),

o emprego do termo dialeto, fora dos estudos científicos, sempre tem sido carregado de preconceito racial e/ou cultural. Nesse emprego, dialeto é uma forma errada, feia, ruim, pobre ou atrasada de se falar uma língua. Também é uma maneira de distinguir as línguas dos povos civilizados, brancos, das formas supostamente primitivas de falar dos povos selvagens. Essa separação é tão poderosa que se enraizou no inconsciente da maioria das pessoas. Inclusive das que declararam fazer um trabalho politicamente correto (Bagno, 2011, p.380, grifos nossos).

3. Eram também chamadas ladim, língua dos pretos, língua do cão e eram proibidas principalmente nas cidades ou nas instituições públicas coloniais (Zamparoni, 1998; 2002; 2009). 
Essa ideologia puramente colonial se enraizou em África e em todos os países que sofreram a colonização. Na citação acima, grifamos alguns adjetivos que eram/ são atribuídos às línguas africanas: erradas, feias, ruins, pobres, atrasadas, etc. Conforme Bagno (2011), essa ideologia consistia em menosprezar as línguas do colonizado em prol das línguas da metrópole. Aliás, o sistema colonial defendia que os países africanos faziam parte da metrópole. Portanto, Moçambique, Angola, Cabo Verde, Guiné-Bissau e São Tomé e Príncipe eram províncias que pertenciam a um país que se localizava na Europa, isto é, Portugal. A ideologia colonial considerava as línguas bantu como sendo atrasadas, sem estrutura, fato que é refutado pelas pesquisas que foram ou estão sendo divulgadas por linguistas.

Concordamos com a tese segundo a qual a "separação entre língua e dialeto é eminentemente política, escapa dos critérios que os linguistas tentam estabelecer para delimitar tal separação" (Bagno, 2011). Consequentemente, o sistema colonial proibia as línguas africanas em sectores da administração pública, isto porque era obrigatório o uso da língua do colonizador. Essa política linguística colonial dividia os africanos em dois grupos: os assimilados ${ }^{4}$ e os não-assimilados ou indígenas (resto da população pobre, analfabeta).Esta questão de 'assimilado' é muito interessante para ser debatido nesta pesquisa porque os "africanos assimilados" renegavam a sua própria identidade, sua cultura e sua língua, quer dizer, passando a se identificar com a cultura europeia/portuguesa do colonizador. Quem tinha acesso a esta formação eram os 'assimilados', porque deviam servir às instituições da administração colonial.

Desta forma, a ideologia colonial cimentou no seio dos africanos a sonegação à sua própria língua, ou melhor, a sua própria identidade. A mesma ideologia continua se verificando nos dias de hoje em todos os PALOP. Em muitas escolas, ainda há professores que proíbem que seus alunos falem as línguas africanas. Quando um aluno fala sua língua materna na escola ou em sala de aula, os professores punem - comportamento e atitude herdados no sistema colonial. Para concluir esta parte, citamos Severo e Makoni (2015, p.72, grifo dos autores) quando destacam que "a política linguística educacional em Moçambique teve que enfrentar um legado ideológico e institucional do período colonial em que aqueles que não falavam português eram considerados incivilizados." Este exemplo é de Moçambique, mas se estende aos restantes países dos PALOP. Vejamos na seção a seguir outros impactos do sistema colonial.

4. O assimilado era um africano desenraizado que cortou os laços culturais com a sociedade africana originária, para adquirir e utilizar "os hábitos e costumes" dos europeus. Para obter esse estatuto, ele devia passar com sucesso um teste que compreendia, entre outras provas, as seguintes: falar e escrever corretamente o português, viver de um trabalho regular e dispor de certo rendimento (Jorge, 2006, p.10). 


\section{Impacto/consequência da política linguística colonial}

A política linguística colonial tinha um único objetivo: dominar os povos africanos através da implementação do sistema colonial. Essa política deu certo, haja vista que todos os africanos 'não-assimilados' sofriam todo tipo de preconceito. Por outro lado, essa segregação racial e linguística despertou a 'consciência africana' que culminou na preparação e luta contra o colonialismo. Sendo assim, "as políticas linguísticas tradicionais desencorajaram o multilinguístico, cultivaram e disseminaram uma única língua oficial, frequentemente a língua metropolitana da antiga potência colonial" (Lopes, 2004, p.237). Curiosamente, muitos africanos renunciaram os seus verdadeiros nomes, em razão dessa assimilação. No Brasil, por exemplo, os africanos e afrodescendentes no período colonial se viram numa situação complicada, isto porque seus nomes africanos eram proibidos. $\mathrm{O}$

aportuguesamento do nome dos africanos e de seus descendentes foi estruturado de maneira violenta e compulsória, contribuiu, assim, como os processos de desenvolvimento identitário e despersonalizado, posto que seus nomes de origem foram substituídos por outros alheios, sem qualquer significado histórico-cultural mais profundo (Fonseca, 2012, p.118).

Essa política colonialista se fez sentir também nos PALOP. Apesar de o colono ter permanecido nestes territórios durante quinhentos anos, nunca mostrou preocupação em valorizar as línguas africanas, aliás, não tinha motivos para valorizar, uma vez que os seus falantes não tinham valor humano e, por isso, não permitiam que as suas línguas fossem também valorizadas. Estamos numa situação conflituosa entre os conceitos de 'língua' e 'dialeto', pois para o colono língua era apenas o português e as africanas eram consideradas como dialeto:

A política assimilacionista implementada por Portugal teve, na imposição da língua portuguesa e consequente proibição da utilização das línguas autóctones, um de seus pontos fortes. Sem o conhecimento da língua portuguesa, todo aquele que pretendesse desfazer-se da categoria de indígena para se tornar um cidadão iria esbarrar com uma impossibilidade (Lopes, 2004, p.230).

Se não havia interesse em valorizar as línguas africanas, também se pode afirmar que não houve, por parte dos colonos, o interesse em ensinar a língua portuguesa aos africanos. Essa língua garantiria o acesso às oportunidades para o grupo restrito de assimilados que serviam à administração colonial, e isso se evidencia pelo fato de que, até o período das independências das colônias, apenas uma pequena parte da população é que sabia falar o português. Em contra partida, logo após as independências dos PALOP, o número de falantes de português aumentou e tem vindo a crescer significativamente. Esse crescimento deve-se às políticas governamentais que incentivam a educação massiva e gratuita nas séries 
iniciais. Acerca do contexto específico de Moçambique, Gonçalves (2012, p. 4) argumenta no sentido de que o crescimento registrado de número de falantes do português no país, para além da política educacional que estimula essa língua, está correlacionado com a pré-disposição da população moçambicana em adotar o português como língua de comunicação em detrimento das LB. Nesse sentido,

o colonialismo português, ao proibir a utilização das línguas autóctones como instrumento de comunicação social, não o fez por querer civilizar os povos africanos. Fê-lo para reprimir, evitar e retardar o aparecimento e o crescimento da consciência nacional. A impossibilidade de obter instrução materna, a degradação cultural e o esquecimento das tradições são sequelas do colonialismo mental. O povo moçambicano não se sentirá completamente reabilitado enquanto não recuperar a sua dignidade de um povo identificável com as suas origens linguísticas e culturais próprias (Lopes, 2004, p.231).

Por isso, muitas línguas bantu não estão descritas, nem têm dicionários, nem gramáticas publicadas e muitas delas ainda são ágrafas. Por exemplo, em Moçambique, só em 2008 é que linguistas conseguiram padronizar a ortografia de dezessete línguas bantu moçambicanas (cf. Ngunga, Faquir, 2011). É importante sublinhar que a língua se relaciona com a sociedade porque é a expressão das necessidades humanas de se congregar socialmente, de construir e desenvolver o mundo. É preciso compreendermos que "a língua não é somente a expressão de alma ou do íntimo ou do que quer que seja do indivíduo; é, acima de tudo, a maneira pela qual a sociedade se expressa, como se seus membros fossem a sua boca" (Lopes, 2004, p.240). Desta forma, a política colonial violou os direitos linguísticos e promoveu a redução das línguas africanas contribuindo para o desaparecimento de várias delas. Sitoe (2014) e Pedro (2014), respondendo à pergunta "estão as línguas nacionais em perigo?", são unânimes ao afirmar que elas resistem ao tempo, às adversidades e às desvantagens atribuídas pelas Constituição da República. Defendem ainda a sua oficialização e o ensino nas escolas. Os autores apoiam o combate aos discursos que inferiorizam e acusam as línguas nacionais como perturbadores da unidade nacional; apoiam o seu uso na vida do país e que sejam integradas "nos planos de desenvolvimento nacional" (Pedro, 2014, p.86).

\section{Particularidades linguísticas do português de África}

A questão das línguas autóctones é um problema não só para os países colonizados por Portugal, mas também para os francófonos, anglófonos etc. Muitos países africanos optaram pela política da oficialização das línguas europeias em prejuízo das suas próprias línguas maternas. Nesta seção, debateremos a questão da língua portuguesa nos PALOP bem como do impacto dos crioulos que tendem 
a crescer a cada dia. Primeiro, veremos Moçambique e Angola (por possuir características linguísticas semelhantes) e, em seguida, passaremos a Guiné-Bissau, Cabo Verde e São Tomé e Príncipe (por possuírem crioulos).

\subsection{Angola e Moçambique}

Tal como vimos no Quadro 2, Moçambique e Angola têm maior contingente populacional e de línguas no espaço dos PALOP. O número da população é dezessete vezes superior aos restantes PALOP. Angola e Moçambique são dois países que tiveram um colonizador comum e que, logo após a independência nacional, adotaram o português como língua oficial. Essa decisão deu-se numa época em que a maior parte da população não falava o português, em um contexto em que existem tantas outras línguas nacionais e que são de domínio mais amplo de moçambicanos e angolanos. Sendo assim, o português passou a ser a língua privilegiada pelo seu papel de língua oficial, em detrimento das demais línguas existentes. Trata-se de um fato que tem as suas raízes no próprio sistema colonial, tendo em conta que durante o período de colonização as línguas africanas foram marginalizadas pelo fato de o seu papel ter sido restringido às comunidades e sem direito a serem usadas em ambientes urbanos.

Os vastos territórios, o grande número da população e a dispersão das etnias pelas diferentes regiões desses países motivaram o não surgimento de casos de pidgins nem de crioulos. O português continuou a ser usado especificamente nas grandes cidades e as línguas africanas permaneceram isoladas em ambientes informais e confinadas aos círculos residenciais periurbanos e rurais, ou seja, cada uma atuando no seu espaço. Infelizmente, depois das independências nacionais, os novos governos não tiveram a devida atenção em tratar esta questão com o maior respeito possível. Assim sendo, as marginalizações que as línguas sofreram no período de colonização continuam ocorrendo nos dias de hoje, mesmo sendo os próprios nacionais que traçam as políticas linguísticas. O português continua, portanto, sendo a única língua de ensino e da administração. No entanto, é preciso reconhecer que ela tem passado por processos de variação se compararmos com a norma-padrão europeia.

Segundo Timbane e Berlinck (2012), a escola encontra dificuldades de ensinar a norma europeia devido aos contextos sociolinguísticos que são diferentes. Nota-se que tanto a norma-padrão como a norma-culta não refletem a comunicação do resto da população que é a maioria, quer dizer, estes conceitos são entidades do estruturalismo e não da sociolinguística. $O$ português de Angola e de Moçambique comprova que as línguas mudam dependendo das variáveis sociais. "A ideia de que o padrão correto é o de Lisboa é uma falsa presunção" (Timbane; 
Berlinck, 2012, p.222). O importante é a criação de dicionários e gramáticas que refletem as variedades do português de Moçambique e de Angola.

\subsection{Guiné-Bissau, São Tomé e Príncipe e Cabo Verde}

Esses três países foram agrupados nesta subseção porque têm características comuns: têm extensões territoriais pequenas, têm uma população não superior a 1.5 milhão e possuem o crioulo como língua dominante. Os crioulos são línguas como quaisquer outras. Elas servem para uma comunicação plena numa determinada comunidade linguística. Uma língua crioula já formada, segundo Lucchesi e Baxter (2009, p.119), "desempenha virtualmente as massas funções comunicativas e sociais que qualquer outra língua natural e é transmitida normalmente de geração para geração, sendo adquirida pelas crianças". De acordo com Cunha (1981), os crioulos se caracterizam pela simplificação gramatical. Mas é importante sublinhar que não existe uma língua simples. É uma simplificação com relação à língua de base - o português.

O crioulo nesses três países é a língua de maior expressão abrangendo a maioria da população. Em Cabo Verde, o crioulo é língua de ensino nas escolas, embora não tenha estatuto de oficialidade. Na Guiné-Bissau e em São Tomé e Princípe, o crioulo é língua nacional, pois é a língua de união das diferentes etnias que esses países têm. Numa situação de multilinguismo, como é o caso de Guiné-Bissau e São Tomé e Príncipe, não haveria entendimento entre as diferentes etnias se não fosse através do crioulo.

Nesse contexto, é importante que os africanos caminhem de forma mais acelerada para a dicionarização do crioulo, bem como para a criação de gramáticas que descrevem o funcionamento dessas línguas. Estamos concordando com a ideia de que deveria haver um debate urgente sobre o Acordo Ortográfico entre os três países para se decidir como grafar (escrever) os crioulos. Sabemos também que o crioulo tem variedade - isso é normal em qualquer língua. $\mathrm{Na}$ Comunidade de Países de Língua Portuguesa (CPLP), já se fala de português brasileiro, português angolano, português moçambicano e por aí em diante. Sabemos-se ainda que existem inglês americano, inglês zimbabweano e por aí adiante, mas com relação aos crioulos guineenses, cabo verdianos e são tomenses deve haver algum consenso quanto a escrita, mesmo sabendo da existência de diversas variedades.

Cabe aos africanos destes países (e a mais ninguém) oficializar o crioulo como língua oficial e nacional para que este patrimônio cultural não se perca ao longo do tempo. Não são decisões simples, pois exigirão dos africanos maior empenho na formação de professores e na criação de manuais (livros) escolares, mas os 
benefícios serão ainda maiores: autoestima elevada, redução de reprovações, redução do preconceito, participação na vida política, entre outros.

\subsection{Guiné Equatorial}

O caso da Guiné Equatorial é específico e realidade nova, pois o país entrou na CPLP em 2011. O espanhol é a primeira língua oficial, seguida pelo francês e, recentemente, pelo português. Para além destas línguas, falam-se os crioulos fang (crioulo de base inglesa) e fá d'ambô (crioulo de base portuguesa) e também as línguas bantu batanga, benga, ngouma, séké e yassa. A Constituição da República de Guiné Equatorial (1995) oficializa apenas o espanhol e reconhece as "línguas aborígenes como integrantes da cultura nacional." Mais uma vez, percebe-se o espaço desprestigiado ocupado pelas línguas africanas no espaço da política linguística, como se essas línguas fossem incapazes, improdutivas e sem capacidade linguística. No espaço lusófono ainda há pouca interação com a Guiné-Equatorial havendo necessidade de entrosamento e circulação de informações de todo tipo: literárias, acadêmico-científico entre outras. Entendemos que a inclusão da Guiné-Equatorial é um momento oportuno de espandir a lusofonia criando oportunidades econômicas, sociais, culturais e principalemnte políticos. Ao acertarmos este país no espaço lusófono criaremos coragem para que a oficialidade do português não fique apenas no papel. Que seja um uso efetivo em todas esferas da sociedade.

\section{Contribuição das línguas no desenvolvimento endógeno}

Entendemos que a ideologia colonial foi acolhida pelos primeiros governantes pós-coloniais. Por quê? Porque se oficializou o português e se desprezou as diversas línguas africanas e os crioulos, tal como o sistema colonial previa. Muitos países africanos deixaram de usar as próprias línguas. No entanto, as línguas africanas e os crioulos podem servir de instrumento para o desenvolvimento da ciência e, consequentemente, da economia. Vejamos:

O 25 de Abril em Portugal provocou uma ruptura brutal entre Portugal e as ex-colônias, com reflexos no continente africano. Quer Portugal, quer as ex-colônias ficaram à deriva, criando teatros socioeconômicos radicais numa conjuntura econômica, política e ideológica mundial tensa, complexa e de destino imprevisível. Convém lembrar que em 1974/75 se verificou a crise econômica mundial até então mais grave no pós-guerra (Murteira, 2010, p.164).

Não se pretende dizer que após a independência devia-se abandonar a língua portuguesa. O que defendemos é o uso das línguas africanas (incluímos crioulos) em paralelo com o português, porque sabemos que as línguas africanas e os 
crioulos são capazes de exprimir qualquer realidade. O português serviria como a língua dos PALOP para contato internacional.

As línguas africanas e os crioulos são línguas completas, com uma estrutura própria e, caso haja algum impasse, elas fazem empréstimos e estrangeirismos linguísticos. Cabral (1990, p.60), por exemplo, questiona como se diz raiz quadrada em balanta? Como se diz aceleração de gravidade nessa língua? A resposta é óbvia: na língua balanta não existem palavras para designar esses conceitos e, por isso, recorre-se aos empréstimos ou estrangeirismos para completar lacunas que possam existir. Dessa forma, a língua balanta pode se socorrer aos empréstimos em português para suprir as lacunas que, por ventura, existam.

Na língua moçambicana xichangana, Ngunga e Simbine (2012, p.303) dão exemplos de kilu, metru, kilometru, milikilu, sentikilu para designar quilo, metro, quilómetro, miligrama, centigrama em português. Esses empréstimos são consenso nas diversas línguas bantu faladas no território. Mas existem empréstimos particulares para cada língua, tal como ilustra Timbane (2012) no artigo "Os empréstimos do português e do inglês na língua xichangana em Moçambique.” Por outro lado, as línguas podem criar novas palavras para nomear esses conceitos. Por exemplo: ntiko (peso), thani (tonelada) e as frações: 1/5=svikhemu svimbirhi ka ntlhanu ou 200/1000.000= mazana mambirhi ya svikhemu ka gidi.

Amilcar Cabral, grande líder e político africano, observou que o mundo avançou muito, mas os africanos permanecem pobres, subdesenvolvidos. Segundo Cabral (1990), os africanos perderam a sua identidade ao perder as suas línguas, isto porque a "língua ficou a nível daquele mundo a que chegamos, que nós vivemos, enquanto o tuga ${ }^{5}$, embora colonialista, vivendo na Europa a sua língua avançou bastante mais do que a nossa língua, podendo exprimir verdades concretas, relativas por exemplo, à ciência" (Cabral, 1990, p.60). Mas ele acrescenta, por outro lado, que "o português é uma das melhores coisas que os tugas nos deixaram, porque a língua, não é prova de mais nada, senão um instrumento, para os homens se relacionarem uns com os outros, é um instrumento, um meio para falar, para exprimir as realidades da vida e do mundo" (Cabral, 1990, p.59, grifo do autor). A língua portuguesa permite que os PALOP possam se comunicar entre si.

É importante sublinhar que "todos os Estados têm o direito soberano e inalienável de escolher o seu sistema econômico, bem como o político, social e cultural, de acordo com os desejos do seu povo sem interferências externas, coerção

5. O termo tuga popularizou-se durante os anos 1960, no decurso da dita "Guerra Colonial", como expressão para designar os portugueses por parte dos guerrilheiros e oposição independentista africana em geral. Tinha como contraponto o termo turra (para terrorista, influenciada por gíria turra (andar às turras), usado pelos portugueses para designar os guerrilheiros independentistas. Ambas as expressões foram, nessa época, entendidas como depreciativas, por serem usadas pelo inimigo. 
ou ameaça, qualquer que seja a sua forma." (Assembleia Geral da Organização das Nações Unidades em Dezembro de 1974). Esse artigo da Organização das Nações Unidades mostra que os líderes africanos precisam pensar não só no seu povo, mas na integração regional e internacional. Investir em línguas africanas (em gramáticas, dicionários, elaboração de manuais e livros escolares, formação de professores) não é perder dinheiro, tal como muitos líderes e políticos pensam. É conservar a identidade, a cultura que sempre nos identificou. Os líderes africanos devem deixar de ver o plurilinguismo como azar, maldição ou mesmo como algo desvantajoso para o desenvolvimento, mas, sim, considerar como o maior tesouro de que um grupo social ou comunidade linguística possui. Sendo assim,

uma política educacional plurilinguista incentivaria o respeito às diferenças culturais e traduziria a importância das línguas maternas na erradicação de processos de exclusão política e social, uma vez que facilitaria a aprendizagem e aumentaria a participação social e política das populações (Rodrigues, 2011, p.62).

Com as independências, os PALOP erraram mais uma vez por atribuir às línguas autóctones funções sociais específicas, porque entendemos que é nesse período que se poderia declarar a independência linguística. Pretendemos dizer que os líderes africanos, ao invés de valorizar as línguas africanas ${ }^{6}$ deram prestígio a língua do colonizador alegando que iriam provocar contendas étnicas. Entendemos que todas as línguas africanas (no espaço PALOP) mereciam o estatuto de oficialidade nos locais onde ocorrem, tal como os exemplos da África do Sul, Quênia e Tanzânia ensinam. Sobre este assunto, Lopes (2004, p.235) defende que "não só as línguas autóctones foram ignoradas, quando não hostilizadas em nome da coesão nacional que era preciso criar e desenvolver, como também pouco ou nenhum esforço foi feito para preservar e desenvolver as riquíssimas potencialidades da tradição oral".

Segundo Abdula (2013), "se o uso das línguas nacionais nas escolas, quer como língua ou como disciplina, é considerado um ganho para a própria educação e para as línguas nacionais, existem ainda elementos não saudáveis que minam este todo interesse nacional" (Abdula, 2013, p.231). O autor se refere aos desafios na preparação dos materiais: dicionários, gramáticas, manuais escolares, formação de professores bem como a intolerância linguística que persiste em todos os PALOP, incluindo nos políticos. Nesse contexto, a educação bilíngue,

6. Tal como aconteceu com suahili, na Tanzânia, o então-presidente Julius Nyerere elaborou uma filosofia de educação denominada Elimu ya kujitegemea (Educação para a autoconfiança), cujo propósito principal era de formar homem de pensamento crítico e questional explorando uma ferramenta importante- a língua bantu local (cf. Rodrigues, 2011). 
por exemplo, é uma forma de preservar essas línguas e fazer com que estejam presentes no seio da sociedade.

Pretendemos defender que é possível aprender as línguas africanas no seio escolar, tal como as experiências da África do Sul, República Democrática de Congo, Tanzânia, entre outras, mostraram. Na luta contra o preconceito linguístico, "a escola deve ser o comandante, posicionando-se na vanguarda e não sendo incentivador da discriminação linguística. $\mathrm{O}$ termo dialeto renega a princípio o estatuto de ser língua e fica com pouca consideração" (Timbane, 2013, p.264). Para além disso, acrescenta-se: é possível estabelecer relações comerciais em línguas africanas?

\subsection{As línguas na economia}

Segundo Ki-Zerbo (2006, p.136), "cabe aos africanos descobrir, inventar novos paradigmas para a sua própria sociedade". Aprender em nossas línguas maternas já é um passo significado para decidirmos o que queremos e para onde vamos. Enquanto África continua a tentar desenvolver-se na base de modelos alheios (europeus), está a contribuir para a sua "desvantagem" econômica. Defendemos aqui a ideia de que os "africanos devem reconstituir-se como entidade, como identidade, como personalidade. A personalidade africana abrange muito mais do que o crescimento econômico" (Ki-Zerbo, 2006, p.124). Do mesmo jeito que acontece com as outras áreas, nenhum sistema de desenvolvimento econômico é feito sem que haja comunicação entre os diferentes intervenientes do processo. Não seria possível serem traçadas filosofias de desenvolvimento econômico, programas de inovação tecnológica e metas a serem alcançadas sem que haja uma base linguística pré-estabelecida, que permita a aquisição do conhecimento tecnológico, a nomeação dos sistemas e o compartilhar dos saberes adjacentes. Independentemente de qual seja o sistema econômico, jamais pode ser implementado sem que um eficaz sistema de comunicação estabelecido.

Um dos motivos que levou os PALOP a adotarem o português como língua oficial foi, para além da criação de uma unidade nacional e do acesso ao saber por via do ensino, também o estabelecimento do desenvolvimento econômico. Haja vista que o português já era uma língua com escrita e com reconhecimento internacional, reunia melhores condições para que as trocas comerciais fossem feitas em nível nacional e internacional e para a criação de parcerias. Mas ressalta-se que a economia de um país não é feita simplesmente pelas trocas comercias entre estados, pois a sua base encontra-se num patamar interno, no qual é feita a produção e a comercialização dos diferentes produtos, até se atingir o nível de exportação. 
Neste contexto, para uma sociedade em que a língua oficial não é a mais falada, as outras línguas nacionais acabam tendo um papel fundamental para que a economia interna se desenvolva. A relação entre os agricultores ou camponeses, a transmissão do conhecimento das épocas agrícolas e das técnicas de irrigação jamais existiriam se a linguagem não estivesse presente. Com isso, vê-se que todo o processo de desenvolvimento econômico passa pela capacidade de interação e de transmissão. Olhando os PALOP, nos quais a maior parte da população não fala o português, o desenvolvimento econômico não se pode dar sem ter em conta as línguas faladas pela maioria da população. Sendo assim, o português, que é a língua oficial, acaba representando um impasse para esse desenvolvimento, visto que todo o processo de desenvolvimento e transmissão de tecnologia é feito na língua que a maior parte da população menos conhece ou não têm domínio.

Para que um desenvolvimento endógeno tenha lugar nestes países, necessariamente, é preciso que haja afirmação das línguas nacionais, fazendo com que elas tenham o mesmo valor funcional que o português. Isso possibilitaria uma maior dinamicidade no desenvolvimento, principalmente nos setores em que a língua tem sido um verdadeiro obstáculo. A partir dessa perspectiva, Rodrigues (2011) sugere cinco pontos necessários para a construção de um desenvolvimento nacional abrangente e genuíno: a) associação entre desenvolvimento econômico, social e cultural; b) autoconfiança em lugar da importação massiva de expertise; c) ajuda intelectual e não material; d) domesticação e nativização de tecnologias importadas, de tal forma que possam se conformar com as normas socioculturais e condições do país e (e) participação das massas e envolvimento das populações pobres (Rodrigues, 2011, p.57).

Nesse trabalho, portanto, está-se propondo o avanço significativo na descrição, criação de dicionários e gramáticas das línguas africanas, para que elas possam passar a ser oficiais, de tal forma que sejam usadas nas trocas comerciais entre os africanos. Seria interessante que os estrangeiros aprendessem as línguas africanas caso queiram estabelecer trocas comerciais com os eles. Por que o mandarim e o japonês são as línguas mais aprendidas atualmente? Por que na África do Sul quase todos falam zulu? Esse é o resultado do planejamento e das políticas linguísticas e econômicas.

\section{Conclusão}

Depois desse debate acerca da importância das línguas no desenvolvimento endógeno de África, é importante sublinhar que os jovens africanos devem partir para a dianteira na decisão dos destinos em todos os aspectos. Em muitas ocasi- 
ões, a 'velha guarda' (na sua maioria ex-combatentes da luta de libertação) tem dado pouco espaço para que os jovens possam expor suas ideias e colocá-las em práticas. As lutas (golpes de estados, instabilidade política etc.) impedem o desenvolvimento pleno. Precisamos "abrir os olhos" para analisar que tipo de ajuda os governantes aceitam, porque muitos deles só criam dívidas que empobrecem os nossos países. Contudo, os problemas que enfermam os PALOP também são visíveis nos países anglófonos.

Rodrigues (2011) na sua obra "A língua inglesa na África: opressão, negociação, resistência" aponta até que ponto as colônias inglesas sofreram ou ainda sofrem as consequências da colonização linguística. Segundo a autora, há ainda discurso ideológico que inferioriza as línguas africanas, aspecto sustentado pela mídia e por políticas educacionais e trabalhistas. Nesse sentido, apesar de o presente capítulo artigo trazer como exemplo os PALOP, o objetivo geral é verdadeiramente apontar para o continente africano como um todo. Não é justo que todo continente tenha os mesmos problemas e impedimentos. É importante procurar soluções para o continente africano, de forma a trazer benefícios que ajudarão a alcançar a sua independência econômica, política e cultural.

É importante aproveitar os recursos linguísticos disponíveis para estabelecer relações comerciais entre os países africanos ao invés de exportar recursos para fora do continente. Por exemplo: não seria mais proveitoso enviar (exportar) camarão para países que se localizam no interior do continente (países sem contato com o mar, oceano) e estabelecer estreitas relações com eles do que mandar esses mesmos recursos para fora do continente? Não seria mais importante Moçambique importar o tomate produzido na África do Sul e comprá-lo a preços aceitáveis do que importar tomate vindo da China ou Japão? Aliás, África do Sul tem línguas inteligíveis com Moçambique. O comércio intra-africano precisa ser pensado de forma mais aprofundada porque ela pode ajudar no desenvolvimento econômico entre os países. Voltando para as questões iniciais, temos a responder que África é o berço da humanidade, mas precisa que os africanos ajam de forma positiva para prestigiar essa realidade ou imagem.

O desenvolvimento de África e dos africanos não virá de fora. É preciso que os próprios africanos tomem a iniciativa de valorizar, preservar, expandir os recursos e as possibilidades, com vistas a se levantar a baixa autoestima que os assola. Tal como Ki-Zerbo (2006) explica, África precisa ser reinventada por forma a responder as necessidades dos próprios africanos e não do ocidente, do oriente, nem de outras potências econômicas mundiais. O desenvolvimento endógeno é possível se os africanos trabalharem para si mesmos, quer dizer, sem exploração indireta e apostando na educação. 
A educação em línguas locais é primordial para o avanço a passos largos para o desenvolvimento. Vários estudos (Ngunga et al., 2010; Pedro, 2014; Sitoe, 2014; Abdula, 2013; Ki-Zerbo, 2006; Kukanda, 2000) mostram claramente como a educação bilíngue pode ajudar na melhoria da qualidade de ensino e na autoestima das crianças e jovens, principalmente nas classes (séries) iniciais. Aliás, a Declaração Universal dos Direitos Linguísticos (Oliveira, 2003), no seu Art. 29 defende que "toda pessoa tem direito a receber educação na língua própria do território onde reside." Para além disso, o Art. 23 aponta que

\begin{abstract}
1. A educação deve contribuir para fomentar a capacidade de auto-expressão linguística e cultural da comunidade linguística do território onde é realizada; 2. A educação deve contribuir para manter e para desenvolver a língua falada pela comunidade linguística do território onde é realizada; 3 . A educação deve estar a serviço da diversidade linguística e cultural e das relações harmoniosas entre diferentes comunidades linguísticas do mundo todo (Declaração Universal dos Direitos Linguísticos, Oliveira, 2003, p.33).
\end{abstract}

Como se pode observar, os governos africanos (especialmente dos PALOP) participaram e ratificaram esta Declaração, mas não houve (e nem há) intenção clara da implementação. Não estaríamos discutindo estes aspectos se a Política Linguística dos PALPOs tivesse tomado um bom caminho (o respeito às línguas locais). Há um distanciamento claro entre as necessidades educativas dos alunos/ da comunidade e a educação formal. Nesse sentido, não é por acaso que os ritos de iniciação ainda são uma prática nas comunidades. É que a escola formal não alimenta as expectativas do povo. Ao contrário: a escola formal procura retomar a política colonial que é da 'civilização dos africanos', quer dizer, fazer com que o aluno africano abandone a sua cultura e práticas tradicionais para seguir a cultura europeia. Está claro que a educação formal está a serviço do eurocentrismo e das práticas ditas civilizadas. Estamos diante de uma colonização e aculturação camuflada, desta feita realizada pelos próprios africanos.

África e os africanos precisam pensar num tipo de sistema educativo que não fira a sua própria identidade. A língua seria um dos instrumentos primordiais para que isso aconteça. O mesmo se pode dizer da economia e da política que não têm se mostrado eficientes. Nos PALOP estamos com uma economia dependente (do Fundo Monetário Internacional, do Banco Mundial e atualmente dependente de chineses) e sem criatividade. Estamos sempre copiando 'modelos' e 'sistemas alheios' que não se adaptam à nossa realidade, cujo resultado se obseva à olho nu: mais de 40 anos de independência e nenhum avanço visível se observou. A população continua miserável, analfabeta ou com analfabetismo funcional e tudo mais. É lamentável que os africanos percam o tempo (que seria do desenvolvimento 
endógeno) com guerras e conflitos intermináveis que provocam a pobreza, fome e, sobretudo, mortes.

As três hipóteses apresentadas no início ficam, assim, confirmadas, devendo cada membro da sociedade, em conjunto com políticos e governos africanos, empreenderem esforços para que as línguas sejam utilizadas na comunicação nacional e internacional. Nesse contexto, há que se salvar as diversas línguas africanas que estão desaparecendo. Rodrigues (2011) as classifica em quatro grupos: línguas vulneráveis, línguas definitivamente ameaçadas, línguas severamente ameaçadas e línguas criticamente ameaçadas. Constata-se que "há 304 línguas ameaçadas de extinção em 36 países africanos” (Rodrigues, 2011, p.25). Precisamos valorizar as nossas línguas usando-as no ensino, e isso passará em primeiro lugar pela criação de instrumento do tipo dicionários, gramáticas, livros para que as crianças africanas tenham o direito de aprender nas suas próprias línguas maternas. A criança, ao descobrir que sua língua materna é importante, começa a valorizá-la e usá-la de forma mais persistente.

Quem quiser estabelecer relações comerciais precisará aprender as nossas línguas para poder se comunicar. Por que o africano precisa aprender alemão para estabelecer relações comerciais com a Alemanha e não o inverso? É que falta autoestima com relação às nossas línguas. Daí a importância deste debate feito ao longo deste capítulo.

O continente africano tem cerca de 2.092 línguas, o que corresponde a 30,3\% das línguas do mundo e só perde para Ásia com 2.269 (32,8\%). Das mais de 6 912 faladas no mundo, 538 línguas estão em via de extinção (Calvet, 2007). Com esses dados, pretendemos mostrar que não é só África que precisa fazer alguma coisa pelas suas línguas. Todo mundo precisa desenhar políticas que preservem e protegem as suas línguas. Mas África precisa fazer mais esforço porque a situação é mais complexa. Terminamos esse debate apresentando algumas sugestões para colocar em prática a visão do desenvolvimento endógeno baseado nas línguas em África: democratização dos planejamentos linguísticos; investimentos em pesquisas para descrição, divulgação e criação de instrumentos do tipo dicionários, gramáticas; oficialização e educação das línguas africanas; aproveitamento de línguas internacionais para o estabelecimento de parcerias e negócios que visam desenvolver a África.

\section{Referências}

Abdula, Rajabo Alfredo Mugabo. O ensino das línguas nacionais como solução para o processo de alfabetização em Moçambique. Letras Dom Alberto. v.1, n³, p.219-232, jan.-jul. 2013. 
Bagno, Marcos. O que é uma língua? Imaginário, ciência e hipótese. In: Lagares, Xoan C.; Bagno, Marcos. (Org.). Políticas da norma e conflitos linguístico. São Paulo: Parábola, 2011, p.355-388.

Cabral, Amílcar. A questão da língua. Papia. v.1, n². Brasília, 1990. p.59-61. Disponível em: $<$ http://abecs.net/ojs/index.php/papia/article/view/188/300>. Acesso em: 31 jul. 2013.

Calvet, Louis-Jean. As políticas linguísticas. Trad. Isabel de Oliveira Duarte, Jonas Tenfen, Marcos Bagno. São Paulo: Parábola, 2007.

Comunidade dos Países de Língua Portuguesa. Estatística da CPLP 2012. Lisboa: INE, I.P, 2013. Couto, Hildo Honório do. Política linguística e planejamento linguístico na Guiné-Bissau. Papia, v.1, n². Brasília. s.d. p.47-57. Disponível em: <http://abecs.net/ojs/index.php/papia/article/ view/187/299 >. Acesso em: 31 jul. 2013.

Cunha, Celso. Língua, nação, alienação. Rio de Janeiro: Nova fronteira, 1981.

Fiorin, José Luiz. Os aldrovandros cantagalos e preconceito linguístico. In: Silva, Fábio Lopes da; Melo Moura, Heronides Maurilio de (Org.). O direito a fala: a questão do preconceito linguístico. 2.ed. Florianópolis: Insular, 2002. p.23-38.

Fonseca, Dagoberto José. Você conhece aquela: a visão, o riso e o racismo a brasileira. São Paulo: Selo Negro, 2012.

Greenberg, Joseph. H. Classificação das línguas em África. In: Ki-Zerbo, Joseph. (Org.). História de África 1: Metodologia e pré-história da África. 2.ed. Brasília: UNESCO, 2010, p.317-344.

Guthrie, Malcolm. The classification of the bantu languages. London/New York: OUP/IAI, 1948.

JORGE, Manuel. Nação, identidade e unidade nacional em Angola: conceitos, preceitos e preconceitos do nacionalismo angolano. Lattitudes. n²8, p.3-10, 2006. Disponível em: <http://www. revues-plurielles.org/_uploads/pdf/17/28/17_28_02.pdf $>$. Acesso em: 30 jun.2017.

Ki-Zerbo, Joseph. Para quando África: entrevista com René Holenstein/Joseph Ki-Zerbo. Trad. Carlos Aboim de Brito. Rio de Janeiro: Pallas, 2006.

Kukanda, Vatomene. Diversidade linguística em África. Africana Studia, nº3, p.101-117. FLUP, 2000

Lopes, José de Sousa Miguel. Cultura acústica e letramento em Moçambique em busca de fundamentos antropológicos para uma educação intercultural. São Paulo: EDUC, 2004.

Luchchesi, Dante; Baxter, Alain. A transmissão linguística irregular. In: Lucchesi, Dante; Baxter, Alain; Ribeiro, Ilza. (Org.). O português afro-brasileiro. Salvador: EDUFBA, 2009. p.101-124.

Malik, Khalid. Índice de desenvolvimento humano de 2014. New York: PNUD, 2014.

Murteria, Mário. Visão e ideologia no desenvolvimento africano. Janus: economia e desenvolvimento, meio século de independência africanas. 2010. p.164-165. Disponível em: <http://www. janusonline.pt/popups2010/2010_3_4_5.pdf>. Acesso em: 20 jul.2013.

Naro, Antonio J.; Scherre, Maria Marta Pereira. Origens do português brasileiro. São Paulo: Parábola, 2007.

Ngunga, Armindo et al. Educação bilíngue na província de Gaza: avaliação de um modelo de ensino. Maputo: CEA/UEM, 2010. 
Ngunga, Armindo; Faquir, Osvaldo G. Padronização da ortografia de línguas bantu moçambicanas: relatório do $3^{\circ}$ seminário. Maputo: CEA, 2011.

Ngunga, Armindo; Simbine, Madalena Cintia. Gramática descritiva da língua changana. Maputo: CEA/UEM, 2012.

Oliveira, Gilvan Muller de (Org.). Declaração Universal dos Direitos linguísticos: novas perspectivas em política linguística. Campinas, SP: Mercado de Letras/ ALB; Florianópolis: IPOL, 2003.

Pedro, José Domingos. Estão as línguas nacionais em perigo. In: Severo, Cristine G; Bento, Bento; Pedro, José. (Org.). Estão as línguas nacionais em perigo? Lisboa: Editora escolar, 2014. p.77-88.

Pereira, F. A. L. Portugal e os países africanos de língua oficial portuguesa (s.d). (Relatório de Estudo). Disponível em: <http://aabdev.files.wordpress.com/2009/05/relatorio-de-estudo-portugal-e-os-palop.pdf>. Acesso em: 22 jun. 2013.

Pereira, Dulce. O essencial sobre a língua portuguesa: crioulos de base portuguesa. Lisboa: Caminho, 2006.

República de Angola. Constituição da República. Luanda. (2010). Disponível em: <http:// www.governo.gov.ao/Arquivos/Constituicao_da_Republica_de_Angola.pdf $>$. Acesso em: 31 jul. 2013.

República de Cabo Verde. Constituição da República. Praia. (1990). <http://www.icrc.org/ ihl-nat.nsf/162d151af444ded44125673e00508141/1437105f604ce363c1257082003ea54a/\$FILE/ Constitution\%20Cape\%20Verde\%20-\%20POR.pdf>. Acesso em: 31 jul. 2013.

República Democrática de São Tome e Príncipe. Constituição da República. São Tomé. (2003). Disponível em: <http://www.icrc.org/ihl-nat.nsf/162d151af444ded44125673e00508141/5365f72 fb2758718c12570a5004ad411/\$FILE/Constitution\%20-\%20Sao\%20Tome\%20-\%20POR.pdf >. Acesso em: 3 jul. 2013.

República de Guiné-Bissau. Constituição da República. Bissau. (1996). Disponível em: < http:// www.didinho.org/Constituicaodarepublicadaguinebissau.htm>. Acesso em: 31 jul. 2013.

República de Guiné-Equatorial. Constituição da República. Malabo. (1995). Disponível em: $<$ http://www.wipo.int/edocs/lexdocs/laws/fr/gq/gq001fr.pdf $>$. Acesso em: 31 jun. 2017.

República de Moçambique. Constituição da República. Maputo. (2004). Disponível em: $<$ http://www.mozambique.mz/pdf/constituicao.pdf>. Acesso em: 31jul.2013.

Rodrigues, Angela Lamas. A língua inglesa na África: opressão, negociação, resistência. Campinas, SP: UNICAMP/FAP, 2011.

Sitoe, Bento. Línguas moçambicanas, como estamos? In: Severo, Cristine G; Bento, Bento; Pedro, José. (Org.). Estão as línguas nacionais em perigo? Lisboa: Editora Escolar, 2014. P.37-76.

Severo, Cristine G. Política(s) linguística(s) e questões de poder. Alfa. n.57, v.2, p.451-473, 2013.

Severo, Cristine G.; Makoni, Sinfree. Políticas linguísticas Brasil-África: por uma perspectiva crítica. v.5. Florianópolis: Insular, 2015. 
Timbane, Alexandre António. Os empréstimos do português e do inglês na língua xichangana em Moçambique. Linguagem: estudos e pesquisas, Catalão, v.16, $\mathrm{n}^{\circ} 1$ e 2, 2012, p.53-79, jan/dez.

Timbane, Alexandre António. A variação linguística e o ensino do português em Moçambique. Confluências. $\mathrm{n}^{\circ} 43,2^{\circ}$ sem. Rio de Janeiro. 2013 p.263-286.

Timbane, Alexandre António.; Berlinck, Rosane Andrade. A norma-padrão europeia e a mudança linguística na escola moçambicana. Gragoatá. no 2, $2^{\circ}$ sem. Niterói. 2012. p.207-226.

Zamparoni, Valdimir D. As escravas perpétuas e o ensino prático: Raça, gênero e educação no Moçambique colonial, 1910-1930. Estudos afro-asiáticos. ano 24, nº 3. 2002. p. 459-482.

Zamparoni, Valdimir D. Entre narros e mulungos: colonialismo e paisagem social em Lourenço Marques c.1890-c.1940. Tese (Doutorado em História Social), Faculdade de Filosofia, Letras e Ciências Humanas, USP: São Paulo, 1998.

Zamparoni, Valdimir D. Colonialismo, jornalismo, militância e apropriação da língua portuguesa em Moçambique nas décadas iniciais do século XX. In: Galves, Charlotte; Garmes, Helder; Ribeiro, Fernando Rosa. (Org.) África-Brasil: caminhos da língua portuguesa. Campinas-SP: UNICAMP, 2009. p.27-56. 